\title{
Experimental challenges with Renibacterium salmoninarum in Arctic charr Salvelinus alpinus
}

\author{
S. Gudmundsdóttir*, Á. Kristmundsson, Í. Ö. Árnason
}

Fish Disease Laboratory, Institute for Experimental Pathology, University of Iceland, Keldur, Keldnavegi 3, 112- Reykjavík, Iceland

\begin{abstract}
Arctic charr Salvelinus alpinus L. is an important species in Icelandic aquaculture and the most common wild salmonid in Iceland. A study on the course of infection with the bacterium Renibacterium salmoninarum was conducted using 3 different challenge methods in brackish and fresh water. Bacterial isolation, ELISA and PCR tests were used for detection of the bacterium in multiple organ samples. In an experiment, run for $34 \mathrm{wk}$ in brackish water, infection was established by intraperitoneal injection with $5 \times 10^{6}$ colony forming units (CFU) fish ${ }^{-1}$. There were external and internal symptoms of bacterial kidney disease (BKD) and mortalities between 6 and 13 wk after injection. A cohabitation trial was run simultaneously and infection was well established after $4 \mathrm{wk}$, as demonstrated by the detection methods applied. Symptoms of BKD were not seen and all but 1 cohabitant survived. In a separate experiment, infection was established by pumping a fixed amount of water from a tank with fingerlings infected by intraperitoneal injection into tanks with naïve fish, in fresh or brackish water, for 6 wk. Fish in the inflow tanks were reared for an additional $3 \mathrm{wk}$. There were neither macroscopic symptoms nor mortalities. ELISA and PCR tests showed that infection started to take hold after $3 \mathrm{wk}$. The challenge trials demonstrated that Arctic charr is susceptible to $R$. salmoninarum. Cohabitation and inflow of water from tanks with infected fish provide useful models for further studies on $R$. salmoninarum infection acquired in a natural way in Arctic charr.
\end{abstract}

KEY WORDS: Renibacterium salmoninarum - Salvelinus alpinus - Challenge methods · Infection state $\cdot$ Diagnostic assays

\section{INTRODUCTION}

Bacterial kidney disease (BKD) is caused by the Gram-positive bacterium Renibacterium salmoninarum (Sanders \& Fryer 1980). It is widespread in wild and cultured stocks of salmonids, in fresh and saline water, and is endemic in many parts of the world (Souter et al. 1987, Jónsdóttir et al. 1998, Meyers et al. 2003, Savas et al. 2006, Chambers et al. 2008). The bacterium can be transmitted horizontally and vertically via the eggs (Evelyn et al. 1986) and survive within mononuclear phagocytes (Gutenberger et al. 1997). BKD can manifest as an acute or chronic disease and frequently causes great losses in aqua-

${ }^{*}$ Corresponding author: siggag@hi.is culture. As antibiotics and vaccines have limited effects, control of BKD relies on monitoring and sanitary methods (Pascho et al. 1991, Gudmundsdóttir et al. 2000).

Arctic charr Salvelinus alpinus L. is the most common wild salmonid in Iceland and the presence of $R$. salmoninarum antigens has been confirmed in a number of wild populations (Jónsdóttir et al. 1998, Arnason et al. 2013, Kristmundsson et al. 2016). Arctic charr and Atlantic salmon Salmo salar L. are the 2 most important species in the country's aquaculture and Arctic charr is reared in fresh as well as brackish water (Árnason et al. 2014). A BKD epidemic affected both species on numerous farms in Iceland in the

(C) The authors 2017. Open Access under Creative Commons by Attribution Licence. Use, distribution and reproduction are unrestricted. Authors and original publication must be credited. 
middle of the last decade (Kristmundsson et al. 2008). With extensive monitoring and stamping out, the infection was eradicated, but the industry had to deal with a serious reduction in production over the following few years (Kristmundsson et al. 2009).

Infection trials, applying various techniques, have been carried out in economically important salmonid species (Fryer \& Lannan 1993), especially rainbow trout Oncorhynchus mykiss (Pascho et al. 1997, Senson \& Stevenson 1999, Jansson et al. 2008) and Chinook salmon Oncorhynchus tshawytscha (Murray et al. 1992, McKibben \& Pascho 1999, Alcorn et al. 2005, Metzger et al. 2010, Elliott et al. 2015). Other species, including Arctic charr, have received less attention: we were able to locate only 2 papers, where Arctic charr, along with other salmonids, were infected with $R$. salmoninarum by intraperitoneal (i.p.) injection. Jones \& Moffitt (2004) studied the swimming endurance of 4 species - bull trout Salvelinus confluentus, lake trout Salvelinus namaycush, Arctic charr and rainbow trout-infected with $R$. salmoninarum, revealing little difference between the species. In the second study, involving bull trout, lake trout, Arctic charr, rainbow trout and Chinook salmon, the emphasis was on temperature-mediated disease expression and survival (Jones et al. 2007). Arctic charr experienced higher mortality after i.p. injection than bull trout and lake trout, but the 3 Salvelinus species showed lower mortality than rainbow trout and Chinook salmon.

The importance of Arctic charr in Icelandic aquaculture and the lack of information in the literature on $R$. salmoninarum infection in this species were the incentives for the experiments reported in this paper. Different infection models and dissemination of the bacterium throughout the body of Arctic charr, using several tests and multiple organ samples, were studied in 2 sets of experiments. In the first set, 2 infection models, i.e. i.p. injection of bacteria and cohabitation, were tested. Intraperitoneal injection is an established, effective and standardized method, but it does not reflect all traits of a natural infection since the route is not natural and important immunological mechanisms, such as mucosal immunity, are evaded (Xu et al. 2013). Cohabitation, where infected fish are used to shed the pathogen into the water, mimics natural waterborne infection and naïve individuals placed in the same tank may acquire a waterborne infection (Alcorn et al. 2005). Following these trials, the question arose whether it would be possible to establish a uniform infection pressure between tanks in a long-standing waterborne challenge. This led to the construction of an experimental setup where rearing water from a tank with infected fish was pumped into several tanks with naïve fish in pathogen-free water. This is hereafter referred to as infection by inflow.

\section{MATERIALS AND METHODS}

\section{Experimental fish}

Arctic charr fingerlings were supplied by Íslandsbleikja at Grindavík (Samherji). The farm is health monitored on a regular basis, a subset of female broodfish is screened annually for Renibacterium salmoninarum and there is no history of BKD for more than 10 yr. The group used in the i.p. injection and cohabitation experiments had an average weight of $100.5 \pm 21.1 \mathrm{~g}( \pm \mathrm{SE})$ and fingerlings with an average weight of $58.8 \pm 12.7 \mathrm{~g}( \pm \mathrm{SE})$ were used in the inflow experiment. The fingerlings were reared in $600 \mathrm{l}$ tanks with continuously running, 9-10 $1 \mathrm{~min}^{-1}$, fresh or brackish (salinity 15\%) pathogen-free borehole water or seawater. The density per volumetric unit was $11.7 \mathrm{~kg} \mathrm{~m}^{-3}$ at the start of the i.p. injection and cohabitation experiments, and $19.6 \mathrm{~kg} \mathrm{~m}^{-3}$ in the inflow experiment. During the trials, the fish were fed 2.5-3.0 mm pellets adapted for Arctic charr (Laxá). The temperature was $7-8^{\circ} \mathrm{C}$ and the oxygen level was $8.3-9.2 \mathrm{mg} \mathrm{l}^{-1}$. Experimental fish were acclimatized for $2 \mathrm{wk}$, and 10 fish were sampled (0-controls) before infection trials were begun. Mortality was recorded every other day during the experiments.

The infection trials were approved and performed in accordance with Act no. 55/2013 and regulation no. 15/1994 of the Icelandic Food and Veterinary Authority, MAST.

\section{Challenge bacterium}

An Icelandic strain of $R$. salmoninarum, S-182-90 (Grayson et al. 2000), was cultivated on kidney disease medium $\mathrm{KDM} 2$ at $16^{\circ} \mathrm{C}$ (OIE 2009). In the i.p. injection and cohabitation experiments, which were conducted simultaneously, bacterial colonies were harvested and suspended in sterile Dulbecco's phosphate-buffered saline (PBS), adjusted to an optical density at $600 \mathrm{~nm}\left(\mathrm{OD}_{600}\right)$ value of 0.7 and used as a stock for bacterial injection. Titration on SKDM agar (OIE 2009) showed $3.5 \times 10^{8}$ colony forming units (CFU) $\mathrm{ml}^{-1}$. In the inflow experiment, the $\mathrm{OD}_{600}$ value of the bacterial solution was adjusted to 0.7 and the solution was used as a stock for bacterial injection of fingerlings, as a source for the infection. 


\section{Challenge methods}

Challenge by i.p. injection was established by injecting $0.2 \mathrm{ml}$ of bacterial solution $\left(5 \times 10^{6} \mathrm{CFU} \mathrm{fish}^{-1}\right)$ into the peritoneal cavity of fingerlings. Tricaine methane sulfonate (TMS/MS222) (PHARMAQ, Vistor) was used at a concentration of $50 \mathrm{mg} \mathrm{l}^{-1}$ to anaesthetise fish prior to injection. A total of 140 individuals were evenly distributed between 2 tanks in brackish water and sampled throughout the experiment, which was run for 34 wk.

Challenge by cohabitation, run for 34 wk in brackish water, was accomplished by i.p. injection of $5 \times$ $10^{7} \mathrm{CFU} \mathrm{fish}^{-1}$ (shedders) that were marked by excising the adipose fin. Fifteen shedders were placed in each of the 2 tanks with 60 naïve fingerlings each, i.e. $20 \%$ of the final group were shedders.

Uninfected fish $(\mathrm{N}=30)$, which served as negative controls for both groups, were reared in a separate tank.

In the inflow experiment, the source of infection was a tank with 160 fingerlings infected by i.p. injection of $0.2 \mathrm{ml}$ of bacterial suspension $\left(2 \times 10^{6} \mathrm{CFU}\right.$ fish $^{-1}$ ). The flow of brackish water (salinity $15 \%$ ) into the tank was 10.5-11.5 $1 \mathrm{~min}^{-1}$. Two of the receiving tanks were supplied with fresh water and 2 with brackish water at an inflow rate of $91 \mathrm{~min}^{-1}$. A pump (Drain it 200, Submersible Pump) was placed at the bottom of the source tank and connected by plastic tubes to the 4 receiving tanks pumping $21 \mathrm{~min}^{-1}$ into each one. The inflow rate was monitored to ensure an even distribution into the tanks. There were 200 uninfected fingerlings in each of these tanks. After $6 \mathrm{wk}$, all the source fish were killed but fingerlings in the 4 inflow tanks were reared for additional $3 \mathrm{wk}$.

\section{Sampling}

When sampled and at the end of the experiments, fish were killed by an overdose of TMS. Fingerlings infected by i.p. injection were sampled 2, 7, 25 and $34 \mathrm{wk}$ after injection and cohabitants were sampled $4,7,10,15,25$ and 34 wk after the trial started. The sampling regime included blood and tissue samples from kidney, spleen, mid-gut and hind-gut.

During the inflow experiment, kidney tissue was sampled from 2 fish in the source tank and 8-12 fish from each set of inflow tanks at weeks 1, 2, 3, 4 and 6 . Additionally, 8 fish from each set of inflow tanks were sampled at week 9. Blood was sampled at weeks 3, 4, 6 and 9 .

Blood was drawn from the caudal vessel and allowed to clot overnight at $4^{\circ} \mathrm{C}$, centrifuged and the sera stored at $-20^{\circ} \mathrm{C}$. Head-kidney and other tissue samples, to be tested by the PCR methods employed, were placed in RNAlater (Applied Biosystems), kept at $4{ }^{\circ} \mathrm{C}$ overnight and stored at $-20^{\circ} \mathrm{C}$. Pieces from head- and mid-kidney were placed in sterile plastic bags and processed on the same day for cultivation on SKDM agar and the remaining kidney tissue was placed in a separate bag and frozen at $-20^{\circ} \mathrm{C}$ until ELISA analysis.

\section{Bacterial isolations}

To screen for common bacterial pathogens, kidney samples were streaked directly on blood agar (BA) or blood agar with $2 \% \mathrm{NaCl}(\mathrm{BA}-\mathrm{NaCl})$, incubated at $16^{\circ} \mathrm{C}$ and observed every other day for a week.

For isolation of $R$. salmoninarum, samples were homogenized, washed and resuspended before inoculation as originally described (Evelyn 1977) and later slightly modified (Benediktsdóttir et al. 1991). After inoculation onto SKDM agar, the plates were incubated at $16^{\circ} \mathrm{C}$ and read once a week for $12 \mathrm{wk}$.

\section{Detection of bacterial antigens by ELISA}

Detection of $R$. salmoninarum antigens, by testing kidney supernatants diluted 1:4 in a double-sandwich ELISA using polyclonal antibodies, was carried out as previously described (Gudmundsdóttir et al. 1993). Sera diluted 1:50 were also tested using the same ELISA method. This high dilution was necessary to diminish the background in serum samples. The cut-off value for determination of positive samples was 2.3 times the average $\mathrm{OD}_{492}$ value of 3 negative control samples.

\section{Extraction and detection of bacterial DNA by PCR methods}

Extraction of DNA for nested PCR (nPCR) and semi-nested PCR (snPCR) was carried out by placing $20 \mu \mathrm{l}$ of homogenized samples diluted 1:4 $\left(\mathrm{w} \mathrm{v}^{-1}\right)$ in sterile Dulbecco's PBS onto an FTA minicard (Whatman). The card was air dried at room temperature for $1 \mathrm{~h}$ and a 2-mm-diameter disc was punched out and placed in a PCR amplification tube. The disc was washed 3 times in the tube with FTA purification reagent (Whatman) and twice with TE buffer (10 mM Tris- $\mathrm{HCl}$ and $0.1 \mathrm{mM}$ EDTA) with $5 \mathrm{~min}$ intervals between each step as described in the manufacturer's protocol. The disc was air dried in the tube for 
$1 \mathrm{~h}$ at room temperature and used as a template in either the nPCR or snPCR reaction. For quantitative PCR (qPCR), a similar sample was placed on an FTA elute card (Whatman) and allowed to dry at room temperature for at least $3 \mathrm{~h}$. The manufacturer's protocol was followed, where a disc was punched out, washed in water and the DNA extracted by incubation in water at $95^{\circ} \mathrm{C}$ for $15-30 \mathrm{~min}$. Negative samples were created for each batch of samples by processing discs punched out of clean cards.

The protocol for nPCR (Pascho et al. 1998) was used with some modifications (Elliott et al. 2013). There are 2 sets of primers that amplify a part of the $R$. salmoninarum msa gene that codes for the major soluble antigen (Table 1). The template used in the first reaction was a disc punched out from an FTA minicard and $1 \mu$ l of the amplified fragment from the first reaction was template in the second reaction. Briefly, the reaction mixture for both the first and the second reaction had a total volume of $25 \mu \mathrm{l}$. The reaction mixture contained sterile water, $0.2 \mathrm{mM}$ of each nucleotide, $2 \mathrm{mM}$ of $\mathrm{MgCl}, 20 \mathrm{mM}$ of Tris- $\mathrm{HCl}(\mathrm{pH}$ 8.4), $50 \mathrm{mM}$ of $\mathrm{KCl}, 1 \mu \mathrm{M}$ of each primers and $0.625 \mathrm{U}$ of Platinum Taq DNA polymerase. Thermal cycling was carried out using a Peltier thermal cycler (PTC$200 \mathrm{MJ}$ research, Bio-Rad) for both the first and second reactions with an initial denaturation step at $94^{\circ} \mathrm{C}$ for $10 \mathrm{~min}$ and followed by 30 cycles of denaturing at $94^{\circ} \mathrm{C}$ for $30 \mathrm{~s}$, annealing at $60^{\circ} \mathrm{C}$ for $30 \mathrm{~s}$ and extension at $72^{\circ} \mathrm{C}$ for $1 \mathrm{~min}$. Samples obtained during the inflow challenge were tested using nPCR.

For one-tube snPCR, 3 primers were designed within the msa gene (Arnason et al. 2013). Two primers, For_msa and Rev_msa, amplify a fragment of 271 base pairs and a third primer, nRev_msa, amplifies the second fragment of 196 base pairs within the first fragment along with the For_msa primer (Table 1).
The melting temperatures for the primers are $57.3^{\circ} \mathrm{C}$ for the For_msa primer, $55.3^{\circ} \mathrm{C}$ for the Rev_msa primer and $50.4^{\circ} \mathrm{C}$ for the nRev_msa primer. The reaction mixture, in a total volume of $25 \mu l$, contained sterile water, $0.24 \mathrm{mM}$ of each nucleotide, $2 \mathrm{mM}$ of $\mathrm{MgCl}$, $24 \mathrm{mM}$ of Tris-HCl (pH 8.4), $60 \mathrm{mM}$ of $\mathrm{KCl}, 1.6 \mu \mathrm{M}$ of For_msa and nRev_msa primers, $0.8 \mu \mathrm{M}$ of Rev_msa primer and $0.625 \mathrm{U}$ of Platinum Taq DNA polymerase (Invitrogen). The template for the reaction mixture was a disc punched out from an FTA minicard. The thermal cycling was done with a Peltier thermal cycler under the following conditions: 12 cycles of amplification (denaturation at $94^{\circ} \mathrm{C}$ for $30 \mathrm{~s}$, annealing at $61^{\circ} \mathrm{C}$ for $2 \mathrm{~min}$ (annealing temperature lowered by $0.5^{\circ} \mathrm{C}$ for each cycle) and extension at $72^{\circ} \mathrm{C}$ for $30 \mathrm{~s}$ ), followed by another 14 cycles of amplification (denaturation at $94^{\circ} \mathrm{C}$ for $30 \mathrm{~s}$, annealing at $55^{\circ} \mathrm{C}$ for $2 \mathrm{~min}$ and extension at $72^{\circ} \mathrm{C}$ for $30 \mathrm{~s}$ ). Yet another 17 cycles of amplification were carried out (denaturation at $94^{\circ} \mathrm{C}$ for $15 \mathrm{~s}$, annealing at $45^{\circ} \mathrm{C}$ for $15 \mathrm{~s}$ and extension at $72^{\circ} \mathrm{C}$ for $15 \mathrm{~s}$ ) along with a final $10 \mathrm{~min}$ elongation period at $72^{\circ} \mathrm{C}$. Prior to the thermal cycling, the samples were heated up to $94^{\circ} \mathrm{C}$ for $10 \mathrm{~min}$ as required for antibody-mediated hot-start of Platinum Taq DNA polymerase. Samples obtained during the i.p. injection and cohabitation challenges were tested using snPCR.

Gel electrophoresis for separation of nPCR and snPCR amplicons was performed on $2 \%$ agarose gels (Saekem) that included ethidium bromide (Sigma). The bands were visualized under UV light and compared with a prestained ladder (1-kb DNA standard, Invitrogen).

In the qPCR test, a 69-bp region from the msa gene was detected (Chase et al. 2006) (Table 1). In the current study, the probe was modified by utilizing a minor groove binding (MGB) linked with a nonfluorescent quencher (NFQ) (Elliott et al. 2013) in-

Table 1. Sequences for primers and probe used to detect DNA from Renibacterium salmoninarum in PCR tests

\begin{tabular}{|c|c|c|c|c|}
\hline $\begin{array}{l}\text { Target } \\
\text { gene }\end{array}$ & $\begin{array}{l}\text { PCR } \\
\text { assay }\end{array}$ & Name & Sequence $\left(5^{\prime}-3^{\prime}\right)$ & Reference \\
\hline \multirow[t]{3}{*}{ msa } & snPCR & For_msa & AGATGGAGCAACTCCGGTTA & Arnason et al. (2013) \\
\hline & & Rev_msa & GGGATTACCAAAAGCGA & \\
\hline & & nRev_msa & TCTCTCAACGCCAATAC & \\
\hline \multirow[t]{4}{*}{ msa } & nPCR & P3 (outer F) & AGCTTCGCAAGGTGAAGGG & Pascho et al. (1998) \\
\hline & & M1 (outer R) & GCAACAGGTTTATTTGCCGGG & \\
\hline & & P4 (inner F) & ATTCTTCCACTTCAACAGTACAAGG & \\
\hline & & M38 (inner R) & CATTATCGTTACACCCGAAACC & \\
\hline \multirow[t]{3}{*}{ msa } & qPCR & RS1238 (F) & GTGACCAACACCCAGATATCCA & Chase et al. (2006) \\
\hline & & RS1307 (R) & TCGCCAGACCACCATTTACC & \\
\hline & & RS1262 NFQ probe & 6FAM-CACCAGATGGAGCAAC-MGB/NFQ ${ }^{\mathrm{a}}$ & \\
\hline
\end{tabular}


stead of tetramethylrhodamine (TAMRA) in the original publication. The total volume of the reaction mixture was $12 \mu \mathrm{l}$, with $0.9 \mu \mathrm{M}$ of forward and reverse primers, $0.25 \mu \mathrm{M}$ of the probe and $5 \mu \mathrm{l}$ of the DNA template. Thermal cycling and analysis were carried out in an ABI 7900HT (Applied Biosystems). Threshold cycle number $(\mathrm{Ct})$ values were grouped in 5 categories: 1 : Ct $35-40 ; 2$ : Ct $30-34.99 ; 3: \mathrm{Ct}$ 25-29.99; 4: Ct 20-24.99; 5: Ct 0-19.99. The weakest responses constitute category 1 and the strongest category 5. Samples obtained during the i.p. injection and cohabitation challenges were tested using qPCR.

\section{RESULTS}

Renibacterium salmoninarum infection was generated in Arctic charr using 3 different challenge methods, i.p. injection, cohabitation and inflow from a tank containing infected fish. Multiple test results from various organs showed that the infection took hold in all exposed individuals. The timescale varied in accordance with the challenge method. Other bacterial fish pathogens were not detected.

\section{Infection by i.p. injection}

An infection was established with mortality of ca. $75 \%$ occurring between Weeks 6 and 13 post-infection. As the group was sampled over the experimental time, an accurate mortality figure could not be determined. Petechiae on the lower abdomen and around the injection site were commonly observed externally, while internally, enlarged and grey kidney, pale liver and empty gut were the prominent observations.

$R$. salmoninarum was isolated on SKDM agar from all kidney samples at Week 2 and $75 \%$ of samples at Week 7 post-infection, while all samples at Weeks 25 and 34 were negative, Fig. 1.

Detection of $R$. salmoninarum antigens, using ELISA, is shown in Fig. 1. Kidney samples were positive at all sampling times with very high readings that were starting to decline at the last sampling point. All but 1 ELISA readings in serum samples were positive at $2 \mathrm{wk}(91.7 \%), 5$ of 12 at $7 \mathrm{wk}$ $(41.7 \%), 3$ of 11 at $25 \mathrm{wk}(27.3 \%)$ and 1 of 8 at $34 \mathrm{wk}$ $(12.5 \%)$. The mean ELISA value for serum samples was highest after $7 \mathrm{wk}\left(\mathrm{OD}_{492}=1.455\right)$.

The snPCR and qPCR results for fish infected by i.p. injection are shown in Fig. 1. At 2 and 7 wk, the majority of samples were positive in all organs. The qPCR categories 4 and 5 were more common at $7 \mathrm{wk}$ than at 2 wk. At Weeks 25 and 34, positive PCR readings were few and mainly obtained by the qPCR method (categories 1 and 2). By pooling all PCR results for Week 25 and Week 34, 6 of 12 and 5 of 8 fish, respectively, tested positive in at least 1 sample by at least 1 of the PCR methods employed. Hence, at the end of the experiment, more than half of the fish had bacterial DNA in at least 1 organ.

\section{Infection by cohabitation}

Samples from the shedders used to establish coinfection in exposed fish were highly positive in all tests 4 wk after injection (results not shown). Mortality reached $73 \%$ at Week 7 and $90 \%$ at Week 10 .

Signs of BKD were not observed in cohabitant fish and only 1 fish died, 3 mo after the experiment started. $R$. salmoninarum was isolated from 1 sample at Week 4, 3 at Week 7 and 1 at Week 25 (Fig. 2).

All kidney samples were positive in ELISA at Week 7 (Fig. 2) and the mean $\mathrm{OD}_{492}$ was highest after $15 \mathrm{wk}$ (3.306). ELISA readings in sera were low with the highest $\mathrm{OD}_{492}$ mean encountered after $10 \mathrm{wk}(0.214)$.

More than half (6-10) of the 12 fish sampled were positive in 1 of the PCR methods at any given sampling time, except that by Week 15, there were only 2 positive fish, 1 with positive qPCR for the mid-gut and the other with positive qPCR for the spleen (Fig. 2). The mid-gut was the only organ with positive samples at all sampling times. All qPCR results fell into categories 1 or 2 .

The 0 -controls for both experiments $(\mathrm{N}=10)$ were negative for $R$. salmoninarum and other bacterial fish pathogens were not detected. Untreated fish $(\mathrm{N}=$ $20)$, reared in a separate tank throughout the $34 \mathrm{wk}$, also tested negative.

\section{Infection by inflow from tank with infected fingerlings}

The fingerlings that were infected by i.p. injection and used as the source of infection showed severe symptoms after $4 \mathrm{wk}$, similar to the fish infected by i.p. injection described above. There were no mortalities at Week 6, but most individuals looked moribund and were killed at that time point. $R$. salmoninarum was isolated on SKDM agar at all sampling times, i.e. 1, 2, 3 and 4 wk after injection, kidney and serum samples showed high readings in ELISA and were positive in nPCR tests (results not shown). Other bacterial pathogens were not isolated. 


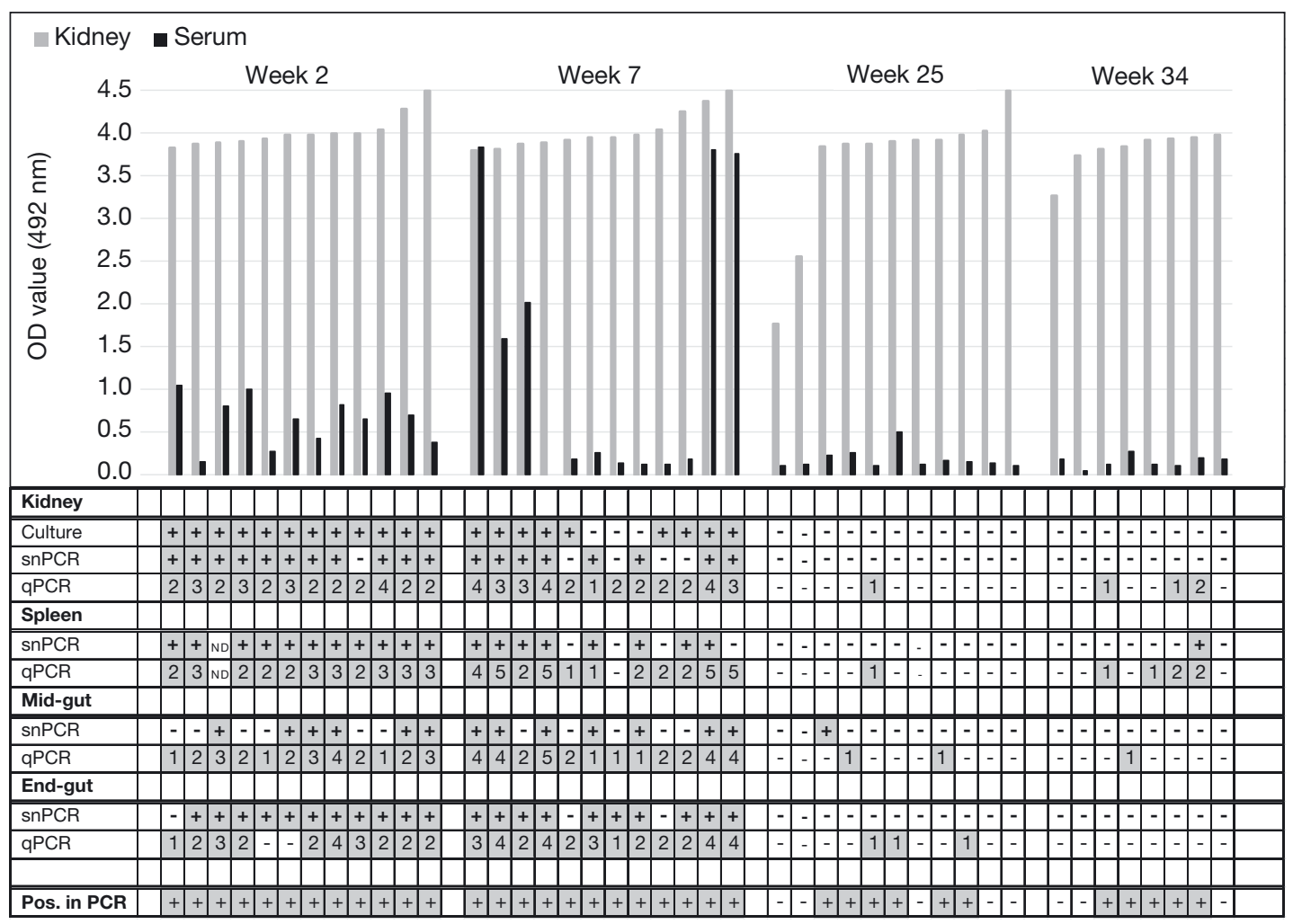

Fig. 1. Results for Arctic charr fingerlings challenged with Renibacterium salmoninarum by i.p. injection and sampled 2, 7, 25 and 34 wk later. The columns represent $\mathrm{OD}_{492}$ values in ELISA for individual kidney tissue samples (grey columns) or serum (black columns) aligned from left to right with increasing OD values for the kidney samples. Below each column there are results for each individual, i.e. culture on kidney samples and 2 PCR tests on samples from kidney, spleen mid-gut and end-gut

The inflow fish, challenged with water continuously pumped from the tank with infected fingerlings, were sampled once a week for 6 wk and finally at Week 9. There were neither symptoms of BKD nor mortalities in fingerlings reared in fresh or brackish water. ELISA readings were similar in both groups (Table 2). Three kidney samples had low positive ELISA readings after $1 \mathrm{wk}$, but all kidney samples were negative at Week 2 and 3 while all serum samples were positive at Week 3. After $4 \mathrm{wk}$, half of the kidney samples and the majority of the serum samples were positive. The reverse was true after $9 \mathrm{wk}$, when all kidney samples and half of the serum samples were positive.

Three out of the 12 kidney samples were positive in nPCR tests after 6 wk in fresh water and 4 of the 12 samples from fish in brackish water were positive at Week 9 (Table 2).

\section{DISCUSSION}

Arctic charr fingerlings were challenged with Renibacterium salmoninarum using 3 different infec- tion models, i.p. injection, cohabitation and inflow from a tank with infected fish. Infection was established with all 3 methods, showing susceptibility to the bacterium. The results also showed that Arctic charr tolerates $R$. salmoninarum infection remarkably well when infected by natural routes such as cohabitation and inflow. Tolerance to infections is defined as the ability of a host to limit the impact of a given pathogen burden on host health and ultimately on host performance (Kause \& Odegard 2012).

The course of infection was studied using 3 kinds of diagnostic tests on tissue samples and sera. The use of results from multiple samples and assays can improve the accuracy of $R$. salmoninarum evaluations, as discussed in recent papers (Elliott et al. 2015, Guðmundsdóttir et al. 2017).

In the i.p. injection trial, infection was already established in every fish tested at the first sampling 2 wk post-injection. Intraperitoneal injection is a widely used, standardized and fast infection method (Jones \& Moffitt 2004, Rhodes et al. 2004, Coady et al. 2006, Jones et al. 2007, Jansson et al. 2008). Comparison of dosages used and survival figures between experiments have to be made with caution since 


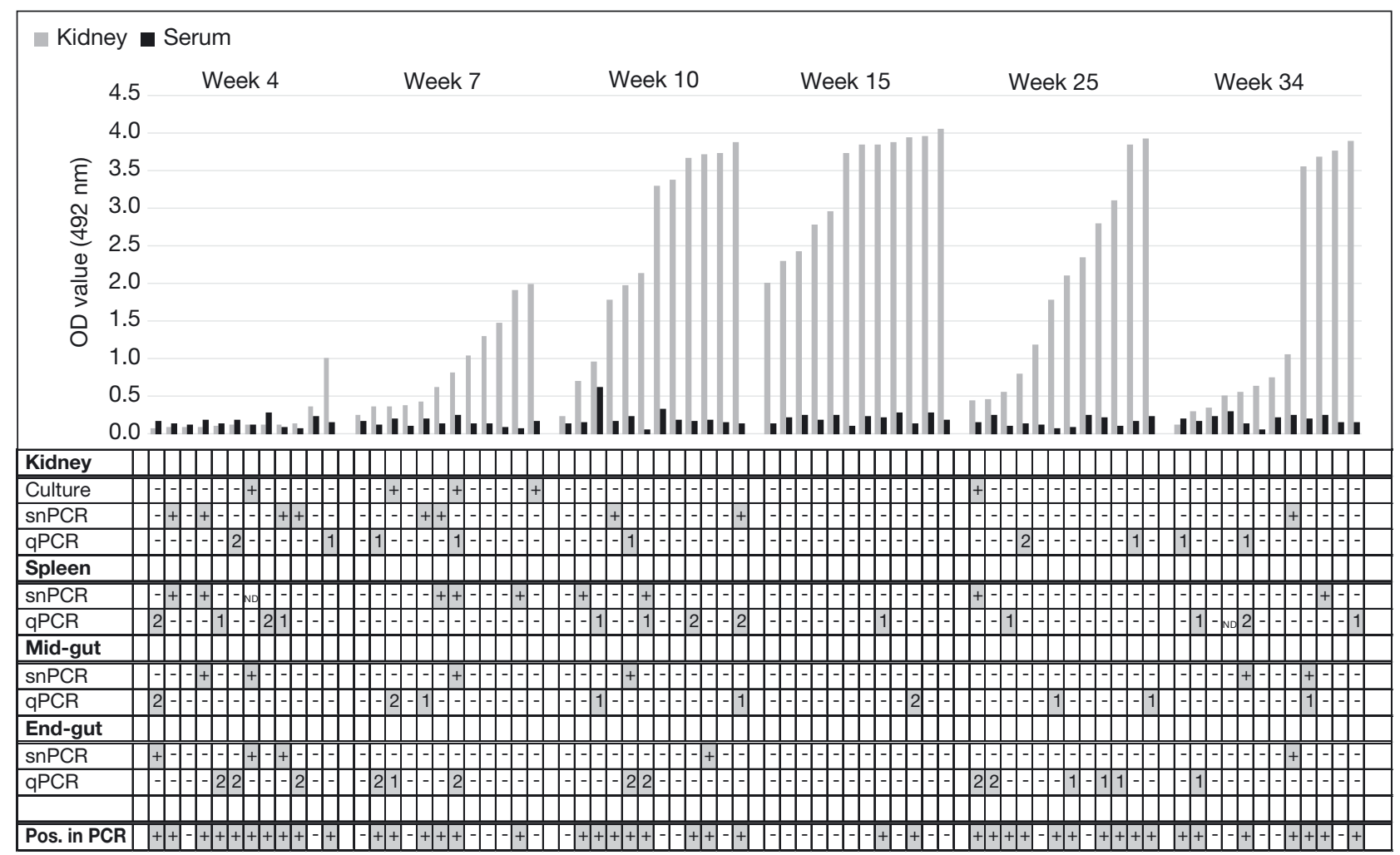

Fig. 2. Results for Arctic charr fingerlings challenged with Renibacterium salmoninarum by cohabitation with shedders infected by i.p. injection. The cohabitants were sampled 4, 7, 10, 15, 25 and 34 wk later. The columns represent OD $_{492}$ values in ELISA for individual kidney tissue samples (grey columns) or serum (black columns) aligned from left to right with increasing OD values for the kidney samples. Below each column there are results for each individual, i.e. culture on kidney samples and 2 PCR tests on samples from kidney, spleen mid-gut and end-gut

many factors, such as strain of bacteria, method of cultivation, conditions in aquaria, different fish species and sizes, may influence the results obtained. $R$. salmoninarum was isolated from all samples at Week 2 and $75 \%$ of samples at Week 7 , but there were no bacterial isolations at Weeks 25 and 34. This does not exclude the possibility that viable bacteria resided in

Table 2. Arctic charr fingerlings reared in fresh and brackish water, challenged by inflow from a tank with fingerlings infected by i.p. injection with $R$. salmoninarum. Bacterial antigens in sera and head-kidney samples were measured by ELISA and nPCR was used to detect bacterial DNA. nd: not done.

\begin{tabular}{|c|c|c|c|c|c|c|}
\hline \multirow{3}{*}{$\begin{array}{l}\text { Weeks } \\
\text { after } \\
\text { infection }\end{array}$} & \multicolumn{3}{|c|}{ Fresh water (no. positive/total) } & \multicolumn{3}{|c|}{ Brackish water (no. positive/total) } \\
\hline & & SA- & nPCR & $-\mathrm{E}$ & $\mathrm{A}-$ & nPCR \\
\hline & Serum & Kidney & Kidney & Serum & Kidney & Kidney \\
\hline 1 & nd & $1 / 8^{a}$ & $0 / 8$ & nd & $2 / 7^{a}$ & $0 / 8$ \\
\hline 2 & nd & $0 / 8$ & $0 / 8$ & nd & $0 / 8$ & $0 / 8$ \\
\hline 3 & $6 / 6$ & $0 / 8$ & $0 / 8$ & $5 / 5$ & $0 / 8$ & $0 / 8$ \\
\hline 4 & $12 / 12$ & $8 / 12$ & $0 / 8$ & $10 / 12$ & $5 / 12$ & $0 / 8$ \\
\hline 6 & $7 / 12$ & nd & $3 / 12$ & $8 / 12$ & nd & $0 / 12$ \\
\hline 9 & $7 / 12$ & $12 / 12$ & $0 / 12$ & $5 / 12$ & $12 / 12$ & $4 / 12$ \\
\hline
\end{tabular}

the kidney in low numbers or in fact elsewhere. There were high ELISA values in serum at Weeks 2 and 7, but background values at Weeks 25 and 34, suggesting clearance of bacteria and bacterial antigens from the circulation. In contrast, the ELISA results for kidney samples showed an abundance of bacterial antigens at all times, indicating accumulation as well as persistence of antigens. Similar results were obtained in a study run for $115 \mathrm{~d}$ where live bacteria were intraperitoneally injected (Coady et al. 2006) and in a study run for $110 \mathrm{~d}$ where killed bacteria were used (Pascho et al. 1997). All kidney samples, except 1 , were positive in SnPCR and/or qPCR at Weeks 2 and 7, while there were few and weakly positive samples at Weeks 25 and 34 , suggesting considerable clearance of the bacterium. Looking at individual fish, 6 of 12 fish at Week 25 and 5 of 8 fish at Week 34, or 
half of all fish tested, had positive PCR results (mainly qPCR test results) in 1 or more organ. Considering all results, the question once more arises whether survivors of $R$. salmoninarum infection suppress or clear the infection.

Cohabitation was successfully established in naïve Arctic charr placed in tanks with fish infected by i.p. injection. Only 1 cohabitant fish died during the course of the experiment and that was 3 mo after it was started. This is different from long-term experiments conducted in Chinook salmon where mortality of cohabitants reached $100 \%$ by Week 25 (Murray et al. 1992) and $26 \%$ by Week 40 (Alcorn et al. 2005). The mechanisms of horizontal transmission are not fully resolved, but ingestion of faecal material from infected fish is an important route of entry (Balfry et al. 1996). It was not determined in the current experiments at what time point the shedders released a consistent amount of bacteria into the environment, as was done in a similar experiment with Chinook salmon where this was accomplished $20 \mathrm{~d}$ after the shedders were injected (McKibben \& Pascho 1999). Since all cohabitants in the current experiment tested positive in 1 or more diagnostic test at the first sampling, 4 wk after the experiment started, it can be concluded that there was a consistent amount of bacteria in the environment before that time point. Looking at the results from the inflow experiment where sera tested positive in ELISA $3 \mathrm{wk}$ after the experiment started and head-kidney tissue a week later, it can be assumed that naïve fingerlings in both experiments started to get infected after approximately $3 \mathrm{wk}$. There were 3 isolations of the bacterium in cohabitants at Week 7, but none at Week 15. At Week 15 , the profile indicated a resolving infection, as modelled previously with kidney samples being ELISA positive and PCR negative (Nance et al. 2010). However, it seems that there were still some fish with viable bacterium, as there was an isolation on agar from 1 fish at Week 25 and more PCR tests were positive at Week 34 than at Week 7 .

The aim of the inflow experiment was to design a natural way to infect groups in several tanks in a uniform manner. The source fish, or shedders, received a high dose of the bacterium and showed clear external signs of infection when they were killed after $6 \mathrm{wk}$. Fingerlings in the receiving tanks were reared for an additional $3 \mathrm{wk}$ and there were neither symptoms nor mortalities when the experiment was ended and there were no differences observed between groups reared in fresh and brackish water. Using ELISA and nPCR to detect bacterial products in kidney and serum samples, it was demonstrated that this in- fection method worked. Fingerlings in the receiving tanks started to turn positive after $3 \mathrm{wk}$ and all tested positive in some test when the experiment was ended at Week 9. In that respect, they mimicked the cohabitants as discussed above. The proportion of positive nPCR tests in kidney samples was comparable to the results seen using SnPCR in the cohabitation group. These tests have previously given equal results when testing the same samples (Arnason et al. 2013). The inflow model offers a natural method of infection where many groups can be subjected to uniform waterborne infection over a long period of time. In immersion models using bathing or dipping, many groups are subjected to the same amount of pathogen over a short period, usually minutes to hours, while in cohabitation, the exposure time is long but the infection pressure between tanks may differ.

Looking at the experiments together, it is clear that $R$. salmoninarum antigens persisted in the kidney and that bacterial DNA was present in some samples from the kidney, spleen and gut throughout the experimental period. Several reports dealing with injection of inactivated or live $R$. salmoninarum have shown similar findings (Pascho et al. 1997, Faisal \& Eissa 2009, Nance et al. 2010). It can be assumed that lymphoid tissue in the head-kidney and spleen as well as mucosa associated lymphoid tissues in the gut are involved in trapping of the bacterium (Press \& Evensen 1999), but it remains an open question whether, or to what extent, the immune system manages to destroy $R$. salmoninarum and degrade its components. The idea to test gut samples is based on the fact that the faecal-oral route is important in horizontal transmission of the bacterium (Balfry et al. 1996), but information on bacterial presence and load in the gut is not available. Positive PCR results for gut samples do not ascertain that all bacteria contributing to a positive PCR were located in the tissue rather than on the surface of the gut. However, the majority of fish with positive gut samples also presented with positive results in the spleen and/or kidney. A noteworthy exception in both groups is Week 25, when the majority of positive samples were gut samples. However, since overall there were few positive samples in Week 25, the significance of this observation cannot be ascertained. High positive ELISA readings in sera were indicative of recent infection in the i.p. injection experiment, but most OD readings were low in the other experiments. Hence, the status of antigens in sera of naturally infected fish is probably not a suitable parameter to ascertain whether an infection is recent or not, and active or not. It is also evident that persistence of antigens in kidney tissue 
makes it impossible to decide, by ELISA results alone, when the fish in question got infected. Persistent antigens could be one of the explanations for the high percentage of positive ELISA readings in kidney samples from groups of wild salmonids in a number of lakes in Iceland (Jónsdóttir et al. 1998) and elsewhere (Meyers et al. 1993, 2003). In a recent paper, reporting on a population of wild brown trout, it was shown that $92.9 \%$ of fish with positive ELISA in kidney samples tested positive by PCR in at least 1 organ (kidney, spleen, gills mid-gut and oesophagus), although culture was negative (Guðmundsdóttir et al. 2017). Persistence of bacterial DNA after the death of a bacterial cell is a controversial subject since bacteria and their environment are diverse. In a review on molecular methods (Pascho et al. 2002), it was concluded that bacterial DNA may be detectable for weeks after the death of bacterial cells, but that free DNA may be degraded quickly. Consequently, positive PCR in studies on $R$. salmoninarum, a Grampositive intracellular bacterium, may represent live bacteria, culturable or unculturable, or bacteria that have been killed but not disintegrated.

In summary, the susceptibility of Arctic charr to $R$. salmoninarum was demonstrated using i.p. injection of bacteria, cohabitation and inflow from a tank with infected fish. There was no mortality in the cohabitation and inflow groups, but multiple test results from various organs indicated that the infection took hold in all exposed individuals. The results further suggested that some individuals may clear the infection, but that viable bacteria will remain in a proportion of the population, so the bacterium is not cleared from the herd. Cohabitation and inflow models will be useful in further studies on natural infection in individual fish as well as in herds and for studying how different external factors may influence any given situation.

Acknowledgements. The authors are indebted to Íslandsbleikja at Grindavík (Samherji hf., Akureyri, Iceland) for providing the fish used in the study, to the staff at Sudurnes Science and Learning Centre for attendance to the experimental fish and to Sigurður Snorrason and Ásthildur Erlingsdóttir for constructive criticism on the manuscript. This work received grants from the AVS R\&D Fund of Ministry of Fisheries and Agriculture in Iceland no. R 10 0093-10 and R 13 074-13.

\section{LITERATURE CITED}

Alcorn S, Murray AL, Pascho RJ, Varney J (2005) A cohabitation challenge to compare the efficacies of vaccines for bacterial kidney disease (BKD) on Chinook salmon (Oncorhynchus tshawytschsa). Dis Aquat Org 63: 151-160

Arnason IÖ, Sigurdardottir S, Kristmundsson A, Svansson V, Gudmundsdóttir S (2013) Evaluation of a semi-nested PCR for detection of Renibacterium salmoninarum in samples from kidney, gill and ovarian fluid of Atlantic salmon broodfish. Icel Agric Sci 26:49-67

Árnason T, Gunnarsson S, Imsland AK, Thorarensen $\mathrm{H}$ and others (2014) Long-term rearing of Arctic charr Salvelinus alpinus under different salinity regimes at constant temperature. J Fish Biol 85:1145-1162

* Balfry SK, Albright LJ, Evelyn TPT (1996) Horizontal transfer of Renibacterium salmoninarum among farmed salmonids via the fecal-oral route. Dis Aquat Org 25:63-69

* Benediktsdóttir E, Helgason S, Gudmundsdóttir S (1991) Incubation time for the cultivation of Renibacterium salmoninarum from Atlantic salmon, Salmo salar L., broodfish. J Fish Dis 14:97-102

Chambers E, Gardiner R, Peeler EJ (2008) An investigation into the prevalence of Renibacterium salmoninarum in farmed rainbow trout, Oncorhynchus mykiss (Walbaum), and wild fish populations in selected river catchments in England and Wales between 1998 and 2000. J Fish Dis 31:89-96

* Chase DM, Elliott DG, Pascho RJ (2006) Detection and quantification of Renibacterium salmoninarum DNA in salmonid tissues by real-time quantitative polymerase chain reaction analysis. J Vet Diagn Invest 18:375-380

Coady AM, Murray AL, Elliott DG, Rhodes LD (2006) Both msa genes in Renibacterium salmoninarum are needed for full virulence in bacterial kidney disease. Appl Environ Microbiol 72:2672-2678

Elliott DG, Applegate LJ, Murray AL, Purcell MK, McKibben CL (2013) Bench-top validation testing of selected immunological and molecular Renibacterium salmoninarum diagnostic assays by comparison with quantitative bacteriological culture. J Fish Dis 36:779-809

*Elliott DG, McKibben CL, Conway CM, Purcell MK, Chase DM, Applegate LJ (2015) Testing of candidate non-lethal sampling methods for detection of Renibacterium salmoninarum in juvenile Chinook salmon Oncorhynchus tshawytscha. Dis Aquat Org 114:21-43

Evelyn TPT (1977) An improved growth medium for the kidney disease bacterium and some notes on using the medium. Bull Off Int Epizoot 87:511-513

* Evelyn TPT, Prosperi-Porta L, Ketcheson JE (1986) Persistence of the kidney-disease bacterium, Renibacterium salmoninarum, in coho salmon, Oncorhynchus kisutch (Walbaum), eggs treated during and after water-hardening with providone-iodine. J Fish Dis 9:461-464

Faisal M, Eissa AE (2009) Diagnostic testing patterns of Renibacterium salmoninarum in spawning salmonid stocks in Michigan. J Wildl Dis 45:447-456

Fryer JL, Lannan CN (1993) The history and current status of Renibacterium salmoninarum, the causative agent of bacterial kidney disease in Pacific salmon. Fish Res 17:15-33

Grayson TH, Atienzar FA, Alexander SM, Cooper LF, Gilpin ML (2000) Molecular diversity of Renibacterium salmoninarum isolates determined by randomly amplified polymorphic DNA analysis. Appl Environ Microbiol 66:435-438

Gudmundsdóttir S, Benediktsdóttir E, Helgason S (1993) Detection of Renibacterium salmoninarum in salmonid kidney samples: a comparison of results using doublesandwich ELISA and isolation on selective medium. J Fish Dis 16:185-195 
Gudmundsdóttir S, Helgason S, Sigurjónsdóttir H, Matthíasdóttir S, Jónsdóttir H, Laxdal B, Benediktsdóttir E (2000) Measures applied to control Renibacterium salmoninarum infection in Atlantic salmon: a retrospective study of two sea ranches in Iceland. Aquaculture 186: 193-203

Guðmundsdóttir S, Applegate LJ, Árnason ÍÖ, Kristmundsson Á, Purcell MK, Elliott DG (2017) Detecting Renibacterium salmoninarum in wild brown trout by use of multiple organ samples and diagnostic methods. Bull Eur Assoc Fish Pathol 37:31-40

Gutenberger SK, Duimstra JR, Rohovec JS, Fryer JL (1997) Intracellular survival of Renibacterium salmoninarum in trout mononuclear phagocytes. Dis Aquat Org 28:93-106

Jansson E, Lindberg L, Säker E, Aspán A (2008) Diagnosis of bacterial kidney disease by detection of Renibacterium salmoninarum by real-time PCR. J Fish Dis 31:755-763

Jones DT, Moffitt CM (2004) Swimming endurance of bull trout, lake trout, Arctic char and rainbow trout following challenge with Renibacterium salmoninarum. J Aquat Anim Health 16:10-22

Jones DT, Moffitt CM, Peters KK (2007) Temperature-mediated differences in bacterial kidney disease expression and survival in Renibacterium salmoninarum-challenged bull trout and other salmonids. N Am J Fish Manage 27:695-706

Jónsdóttir H, Malmquist HJ, Snorrason SS, Gudbergsson G, Gudmundsdóttir S (1998) Epidemiology of Renibacterium salmoninarum in wild Arctic charr and brown trout in Iceland. J Fish Biol 53:322-339

Kause A, Odegard J (2012) The genetic analysis of tolerance to infections: a review. Front Genet 3:262

Kristmundsson Á, Helgason S, Gudmundsdóttir S (2008) Epidemiology of Renibacterium salmoninarum in farmed salmonids in Iceland. In: Proc Int Conf on Fish Diseases and Fish Immunology, Reykjavík, Iceland, Book of Abstracts

Kristmundsson Á, Helgason S, Gudmundsdóttir S (2009) Bacterial kidney disease in salmonids in Iceland. Veidimadurinn 188:64-66 (in Icelandic)

Kristmundsson Á, Árnason F, Gudmundsdóttir S, Antonsson T (2016) Levels of Renibacterium salmoninarum antigens in resident and anadromous salmonids in the River Ellidaár system in Iceland. J Fish Dis 39:681-692

McKibben CL, Pascho RJ (1999) Shedding of Renibacterium salmoninarum by infected Chinook salmon Oncorhynchus tschawytscha. Dis Aquat Org 38:75-79

Metzger DC, Elliott DG, Wargo A, Park LK, Purcell MK (2010) Pathological and immunological responses associated with differential survival of Chinook salmon following Renibacterium salmoninarum challenge. Dis Aquat Org 90:31-41

Meyers TR, Short S, Farrington C, Lipson K, Geiger HJ, Gates R (1993) Comparison of the enzyme-linked immunosorbent assay (ELISA) and the fluorescent antibody test (FAT) for measuring the prevalences and levels of Renibacterium salmoninarum in wild and hatchery stocks of salmonid fishes in Alaska, USA. Dis Aquat Org $16: 181-18$

Meyers TR, Korn D, Glass K (2003) Retrospective analysis of antigen prevalences of Renibacterium salmoninarum (Rs) detected by enzyme-linked immunosorbent assay in Alaskan Pacific salmon and trout from 1988 to 2000 and management of Rs in hatchery Chinook and coho salmon. J Aquat Anim Health 15:101-110

* Murray CB, Evelyn TPT, Beacham TD, Barner LW, Ketcheson JE, Prosperi-Porta L (1992) Experimental induction of bacterial kidney disease in Chinook salmon by immersion and cohabitation challenges. Dis Aquat Org 12: 91-96

Nance SL, Riederer M, Zubkowski T, Trudel M, Rhodes LD (2010) Interpreting dual ELISA and qPCR data for bacterial kidney disease of salmonids. Dis Aquat Org 91: 113-119

OIE (World Organisation for Animal Health) (2009) Manual of diagnostic tests for aquatic animals, 6 th edn. OIE, Paris

* Pascho RJ, Elliott DG, Streufert JM (1991) Brood stock segregation of spring Chinook salmon Oncorhynchus tshawytscha by use of the enzyme-linked immunosorbent assay (ELISA) and the fluorescent antibody technique (FAT) affects the prevalence and levels of Renibacterium salmoninarum infection in progeny. Dis Aquat Org 12: 25-40

* Pascho RJ, Goodrich TD, McKibben CL (1997) Evaluation by enzyme-linked immunosorbent assay (ELISA) of Renibacterium salmoninarum bacterins affected by persistence of bacterial antigens. J Aquat Anim Health 9: 99-107

Pascho RJ, Chase D, McKibben CL (1998) Comparison of the membrane-filtration fluorescent antibody test, the enzyme-linked immunosorbent assay, and the polymerase chain reaction to detect Renibacterium salmoninarum in salmonid ovarian fluid. J Vet Diagn Invest 10: 60-66

Pascho RJ, Elliott DG, Chase DM (2002) Comparison of traditional and molecular methods for detection of Renibacterium salmoninarum. In: Cunningham CO (ed) Molecular diagnosis of salmonid diseases. Kluwer Academic publishers, Dordrecht, p 157-209

Press MC, Evensen O (1999) The morphology of the immune system in teleost fish. Fish Shellfish Immunol 9:309-318

* Rhodes LD, Rathbone CK, Corbett SC, Harrell LW, Strom MS (2004) Efficacy of cellular vaccines and genetic adjuvants against bacterial kidney disease in Chinook salmon (Oncorhynchus tshawytscha). Fish Shellfish Immunol 16:461-474

Sanders JE, Fryer JL (1980) Renibacteriun salmoninarum gen. nov. sp. nov., the causative agent of bacterial kidney disease in salmonid fishes. Int J Syst Bacteriol 30: 496-502

Savas H, Altinok I, Cakmak E, Firidin S (2006) Isolation of Renibacterium salmoninarum from cultured Black Sea salmon (Salmo trutta labrax): first report in Turkey. Bull Eur Assoc Fish Pathol 26:238-246

* Senson PR, Stevenson RMW (1999) Production of the $57 \mathrm{kDa}$ major surface antigen by a non-agglutinating strain of the fish pathogen Renibacterium salmoninarum. Dis Aquat Org 38:23-31

Souter BW, Dwilow AG, Knight K (1987) Renibacterium salmoninarum in wild Arctic charr Salvelinus alpinus and lake trout $S$. namaycush from the Northwest Territories, Canada. Dis Aquat Org 3:151-154

Ku Z, Parra D, Gomez D, Salinas I and others (2013) Teleost skin, an ancient mucosal surface that elicits gut-like immune responses. Proc Natl Acad Sci USA 110: 13097-13102

Submitted: September 2, 2016; Accepted: February 1, 2017 Proofs received from author(s): March 15, 2017
Editorial responsibility: Andrew Barnes,

Brisbane, Queensland, Australia 